\title{
APPLICATION OF INFRARED SPECTROMETRY IN STUDYING FUELS AND BIOFULES FOR AIRCRAFT TURBINE ENGINES
}

\section{Zastosowanie spektrometrii w podczerwieni w badaniach paliw i biopaliw do turbinowych silników lotniczych}

\begin{abstract}
The research paper presents hydrocarbon biocomponents approved for use in aircraft turbine engines. The properties of these biocomponents are governed by ASTM D 7566 standard. One of the new issues regarding the utilization of fuels for aircraft turbine engines is the identification of non-petroleum elements, including hydrocarbon biocomponents. This article proposes applying infrared spectrometry as a technique for instrumental analysis, which enables quick and qualitative identification of a used hydrocarbon biocomponent. Differences in the infrared spectrum between the mineral fuel and used fuel biocomponent were indicated based on the conducted preliminary tests.
\end{abstract}

Keywords: infrared spectrophotometry, fuel for aircraft turbine engines, hydrocarbon biocomponent

Streszczenie: W artykule przedstawiono dopuszczone do stosowania $w$ turbinowych silnikach lotniczych biokomponenty węglowodorowe. Własności tych biokomponentów reguluje norma ASTM D 7566. Jednym z nowych problemów w eksploatacji paliw do turbinowych silników lotniczych jest identyfikacja nienaftowych komponentów, w tym węglowodorowych biokomponentów. W niniejszym artykule zaproponowano wykorzystanie spektrometrii w podczerwieni, jako techniki analizy instrumentalnej umożliwiajacej szybka, jakościowa identyfikację zastosowanego biokomponentu węglowodorowego. Na podstawie przeprowadzonych wstępnych badań wskazano różnice $w$ widmie $w$ podczerwieni, między mineralnym paliwem, a użytym biokomponentem paliwowym.

Słowa kluczowe: spektrofotometria w podczerwieni, paliwo to turbinowych silników lotniczych, biokomponent węglowodorowy 


\section{Introduction}

The dynamic development of road and air transport, which occurred at the turn of the 20 th and 21 st centuries resulted in an unexpectedly rapid increase in the demand for mineral fuels obtained from petroleum processing, It was noticed that the reserves of this natural resource had been depleting rapidly and with such a huge demand, they would secure the global needs for around 40 years. This resulted in a need to replace natural fuels with substitutes, which can be obtained from renewable sources.

Another important reason for substituting mineral fuels is the greenhouse effect. As a result of the intensive development of road and air transport, $\mathrm{CO}_{2}$ emissions have increased. Many countries decided to implement a scheme aimed at halting $\mathrm{CO}_{2}$ emission increase by using biofuels [5].

Biocomponents and biofuels were implemented in the field of road transport around 20 years ago. The biocomponents commonly used for composing fuels are: FAME as a biocomponent of diesel oil and bioethanol, as a biocomponent of car gasolines. When it comes to aviation fuels, the last decade has seen the development of hydrocarbon biofuel production technologies, which will be intended for supplying compression ignition and turbine aircraft engines [5]. When analysing the latest technical literature, it can be observed that the globally conducted research indicate that the biocomponents used in aviation will be the bio-hydrocarbons - hydrocarbon components obtained from biomass. Such biocomponents have a chemical structure similar to petroleum-based fuels, however unfortunately, their properties differ from the mineral fuels used so far.

The basic document, which governs international aviation regulations is a Convention signed in Chicago on 7 December 1944. It presents a general division into civilian and state aviation. On a European scale, the leading document for civil aviation is: Commission Regulation (EC) No. 859/2008 of 20 August 2008 amending Council Regulation (EEC) No. 3922/91 on the harmonization of common technical requirements and administrative procedures in the field of civil aviation, as regards to the common technical requirements and administrative procedures applicable to commercial transport by aeroplane, whereas in Poland, the basic legal act, the provisions of which fully apply to civilian aviation is the Act of 3 July 2002, the Aviation Law. In the case of Polish Air Forces, at the level of the chief authority, it is governed by the Decision of the Minister of National Defence, whereas at the level of the central authority, by numerous military institutions independent from each other, such as: Combined Forces General Command, Polish Army General Staff, Air Forces Inspectorate, Inspectorate for Armed Forces Support, Combined Forces Operation Command, or Incident Investigation Committee (KBWL LP). The standardization of the security system is hindered due to such an organization state, which disperses competence and decision-making powers within the air forces onto numerous military institutions. The technical requirements and the manner of handling aviation fuel are governed by international JIG standards, which refer to two ASTM standards governing the process of certification for a new product: 
- ASTM D 4054 - Standard Practice for Qualification and Approval of New Aviation Turbine Fuels and Fuel Additives,

- ASTM D 7566 - Standard Specification for Aviation Turbine Fuel Containing Synthesized Hydrocarbons.

\section{Types of synthetic fuels approved for use}

The standard ASTM D 7566 "Standard Specification for Aviation Turbine Fuel Containing Synthesized Hydrocarbons" [1] lists the types of synthetic fuels, which can be added to mineral aviation fuel and specifies the minimum quality requirements for individual biocomponents. This standard describes five types of hydrocarbon biocomponents that differ in physical and chemical properties, with the differences resulting from the applied production technology.

1. Annex A.1 - specifies the requirements for paraffinic kerosene (FT-SPK) obtained as a result of Fischer-Tropscha synthesis. This process utilizes fractions of biodegradable, solid municipal, agricultural and forestry waste, as well as biomass obtained from targeted wood and energy crops.

2. Annex A.2 - specifies the requirements for paraffinic kerosene (HEFA-SPK) obtained as a result of hydrorefining esters and fatty acids. This process uses mainly fats.

3. Annex A.3 - specifies the requirements for synthetic isoparaffin (SIP) obtained as a result of sugar fermentation. This process mainly utilizes bakery and confectionery products.

4. Annex A.4 - specifies the requirements for synthetic paraffinic kerosene enriched with flavours (FT-SPK/A), obtained as a result of Fischer-Tropscha synthesis, in which the content of aromatic compounds is deliberately increased by alkylating light flavours not originating from crude oil (mainly benzene). This process mainly utilizes biomass from solid municipal, agricultural and forestry waste.

5. Annex A.5 - specifies the requirements for synthetic alcohol-to-jet kerosene (ATJSPK), where isobutanom or ethanol is subjected to a number of dehydration, oiligomerisation and hydrogenation processes. This process mainly utilizes isobutanol from renewable sources, like sugar, corn or forestry waste.

The application of various technologies for the production of individual hydrocarbon biocomponents results in the aforementioned hydrocarbon biofuels exhibiting different qualitative composition. One of the new issues regarding the utilization of fuels for aircraft turbine engines is the identification of non-petroleum elements, including hydrocarbon biocomponents. This article presents the results of initial research on the application of infrared spectrometry as a technique for instrumental analysis, which enables quick and qualitative identification of a used hydrocarbon biocomponent. 


\section{Infrared spectrometry - introduction}

The infrared range covers the electromagnetic radiation spectrum between the visible and microwave areas, i.e., between 14300 and $200 \mathrm{~cm}^{-1}$. In terms of studying the structure of chemical compounds, the specific infrared area $\left(4000-700 \mathrm{~cm}^{-1}\right)$ has the greatest designation, with far (700-200 $\left.\mathrm{cm}^{-1}\right)$ and near infrared (14300-4000 $\left.\mathrm{cm}^{-1}\right)$ adjacent to it. Oscillation-rotation transitions correspond to radiation absorption within the range of 4000$700 \mathrm{~cm}^{-1}[4]$.

Function groups, as well as other characteristic atom groups usually absorb infrared radiation within a relatively narrow frequency range, regardless of the remaining structure of the molecule. This is why infrared spectroscopy is an irreplaceable method for the identification of function groups and other compound structural elements [4].

Even simple chemical compounds have such a complicated infrared spectrum that comparing two substance spectra is an excellent test of their identity. This is because it does not happen for two different compounds, not being enantiomers, to have identical infrared spectra [4].

Infrared radiation absorption causes oscillating and rotating excitation energy, with the oscillating excitations playing a more important role, since they have higher energy than rotating excitations. There are two types of oscillating vibration distinguished in a molecule:

- deformation vibrations, e.g.: shortening, shearing and swaying, which cause a change in the angle between atom bonds,

- symmetrical or asymmetrical tensioning vibrations, which are characterized by a rhythmic movement along the bond axis, and causing the distance between the atoms to decrease or increase.

The measurement technique can be divided into transmissive and reflective. The transmissive technique, through measuring the intensity of radiation passed through a sample, provides an oscillation spectrum. Liquid and gas samples are determined in measurement vessels called cells, which have windows made of materials transparent for infrared, i.e.: $\mathrm{KBr}, \mathrm{NaCl}, \mathrm{ZnSe}$, whereas the spectra of solid samples can be measured in disks made of, e.g.: lithium group halogens in a Nujol suspension (liquid paraffin), on silicon plates. The reflective technique enables obtaining an infrared spectrum through measuring radiation reflected from a sample. Reflected radiation is measured by various optical systems used in spectrometer attachments. The method of attenuated total internal reflection (ATR) utilizes the phenomenon of total internal reflection of the light [3], is dedicated to solid samples, and regardless of their thickness provides a qualitative spectrum.

\section{Interpreting infrared spectra}

An infrared spectrum is a graph of absorption dependency on radiation energy. A measure of absorption is the beam intensity - transmittance or its absorptive converse. 
Full spectral absorption is difficult because there are numerous deformation and tensioning vibrations within a single molecule. The spectrum contains many various bands corresponding to such vibrations. Individual types of bonds have a similar difference in the energy between oscillation levels, absorb radiation of characteristic frequency, providing a band within the same range, regardless of other molecule structure details. This means that the same function groups (e.g. $\mathrm{C}=\mathrm{O}, \mathrm{N}-\mathrm{H}, \mathrm{O}-\mathrm{H}$ ) in different compounds, provide characteristic absorption bands, which fall within a comparable range of wave numbers. For identification purposes, the area of the $4000-400 \mathrm{~cm}^{-1}$ wave number range can be divided into four sections:

1. The 4000-2500 $\mathrm{cm}^{-1}$ area corresponds to absorption most frequently resulting from the presence of $\mathrm{N}-\mathrm{H}, \mathrm{C}-\mathrm{H}-, \mathrm{O}-\mathrm{H}$ groups in the molecule. The bands in this range correspond to tensioning vibrations.

2. In the $2500-2000 \mathrm{~cm}^{-1}$ area the absorption bands indicate the presence of groups containing triple bonds, e.g. $\mathrm{C} \equiv \mathrm{C}$ alkynes and $\mathrm{C} \equiv \mathrm{N}$ nitriles in the compound.

3. In the 2000-1500 $\mathrm{cm}^{-1}$ area the bands come mainly from various types of tensioning vibrations of double bonds $(\mathrm{C}=\mathrm{O}, \mathrm{C}=\mathrm{C}, \mathrm{C}=\mathrm{N})$.

4. The range below $1500 \mathrm{~cm}^{-1}$, called "the dactyloscopic range" has a band system characteristic for a given molecule. It contains tensioning vibration bands for single bonds, e.g., C-C, C-O or C-N and many bands corresponding to deformation vibrations. This range is used to identify a studied substance based on comparing an infrared spectrum with a reference compound spectrum, and just like in dactyloscopy, the "fingerprint" range identity is a confirmation of the identity between the tested compound and a reference compound [4].

\section{Result analysis}

An infrared spectrum for a sample of the JET A-1 aviation fuel and two HEFA-SPK and ATJ-SPK hydrocarbon components was developed in order to determine the possibility of using infrared spectroscopy. The measurement was conducted in a cell with a variable optical path and $\mathrm{ZnSe}$ slides.

Figures 1 and 2 show infrared spectra for the JET A-1 aviation fuel and a HEFA hydrocarbon biofuel, which was obtained as a result of ester and fatty acid hydrorefining process. 


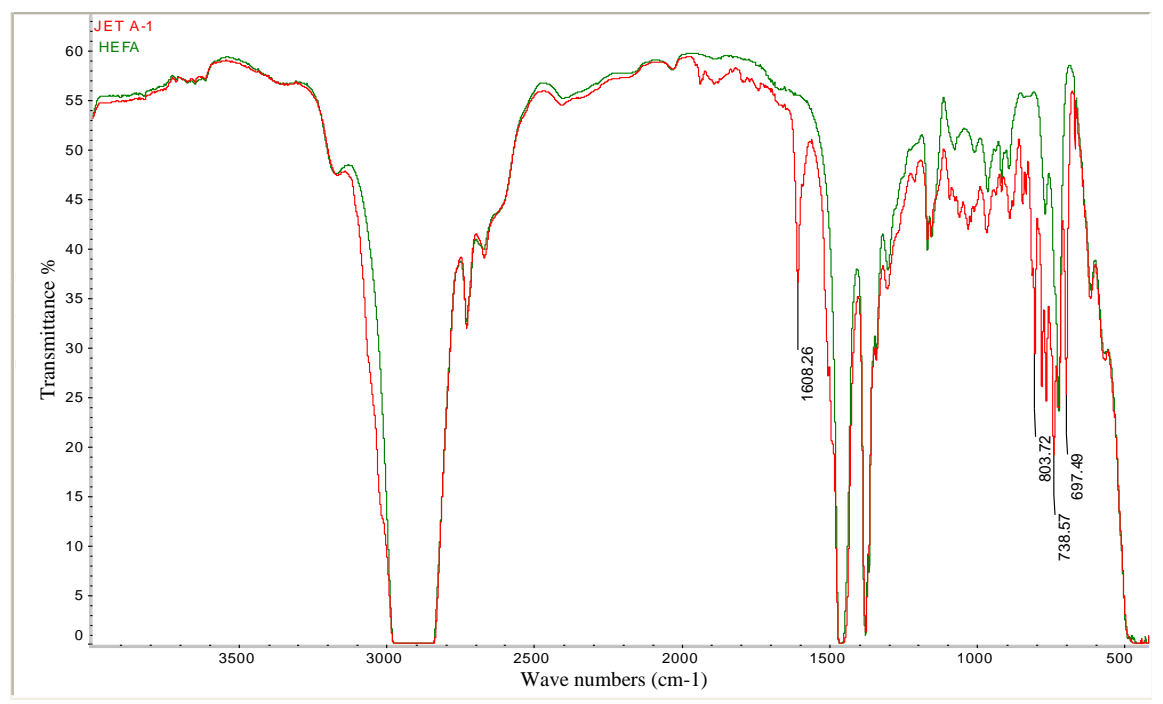

Fig. 1. Total infrared spectrum for the JET A-1 aviation fuel and a hydrocarbon biofuel in the HEFA technology

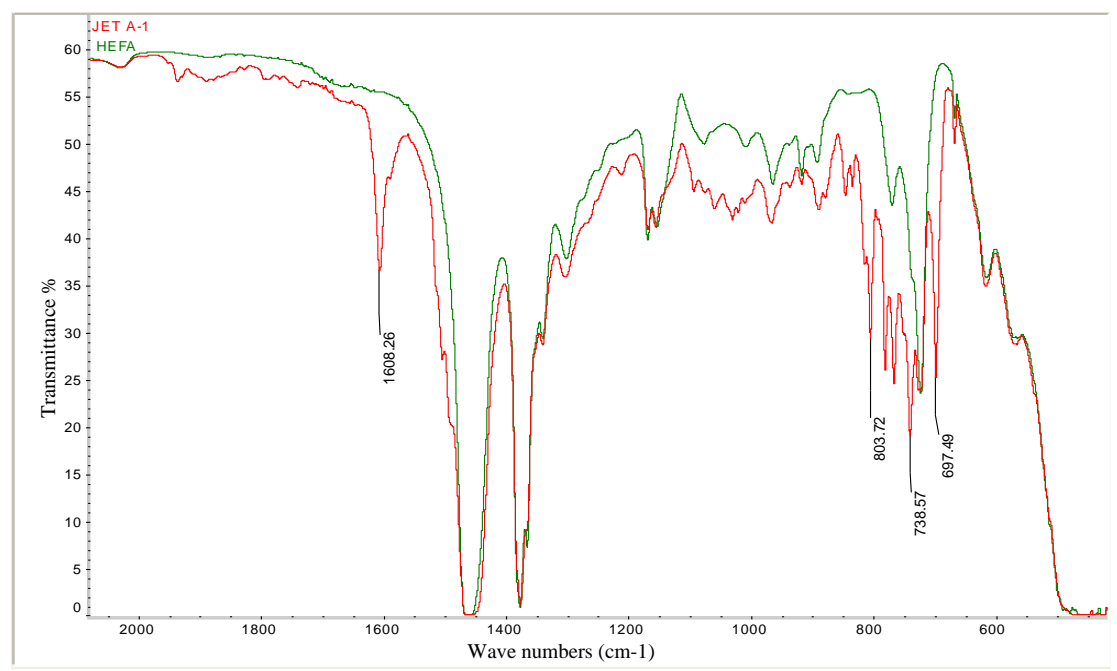

Fig. 2. Infrared spectrum for the JET A-1 aviation fuel and a hydrocarbon biofuel in the HEFA technology for the wave number range of $2000-500 \mathrm{~cm}^{-1}$

When analysing these infrared spectra, significant differences in the area of the 2000$-1500 \mathrm{~cm}^{-1}$ wave number can be observed, with the hydrocarbon component in this area without characteristic peaks, which are exhibited by the JET A-1 fuel. A long, sharp peak 
with a wave number of approximately $1600 \mathrm{~cm}^{-1}$ appears when aromatic compounds are present, and is provided by the $\mathrm{C}=\mathrm{C}$ bond, which can be found in the aromatic ring. Differences in the recorded infrared spectra are noticeable for the wave number range of $1500-700 \mathrm{~cm}^{-1}$. In the case of the JET A-1 aviation fuel and a wave number range of 900$-600 \mathrm{~cm}^{-1}$, we can see peaks, which are characteristic for the $\mathrm{C}-\mathrm{H}$ bond in the $\mathrm{sp}^{2}$ configuration, within the aromatic ring, with mono- and para-substituents by the aromatic ring responsible for that.

Figures 3 and 4 show infrared spectra for the JET A-1 aviation fuel and the ATJ hydrocarbon biofuel obtained using a technology, where isobutanol or ethanol is subjected to a number of dehydration and hydrogenation processes.

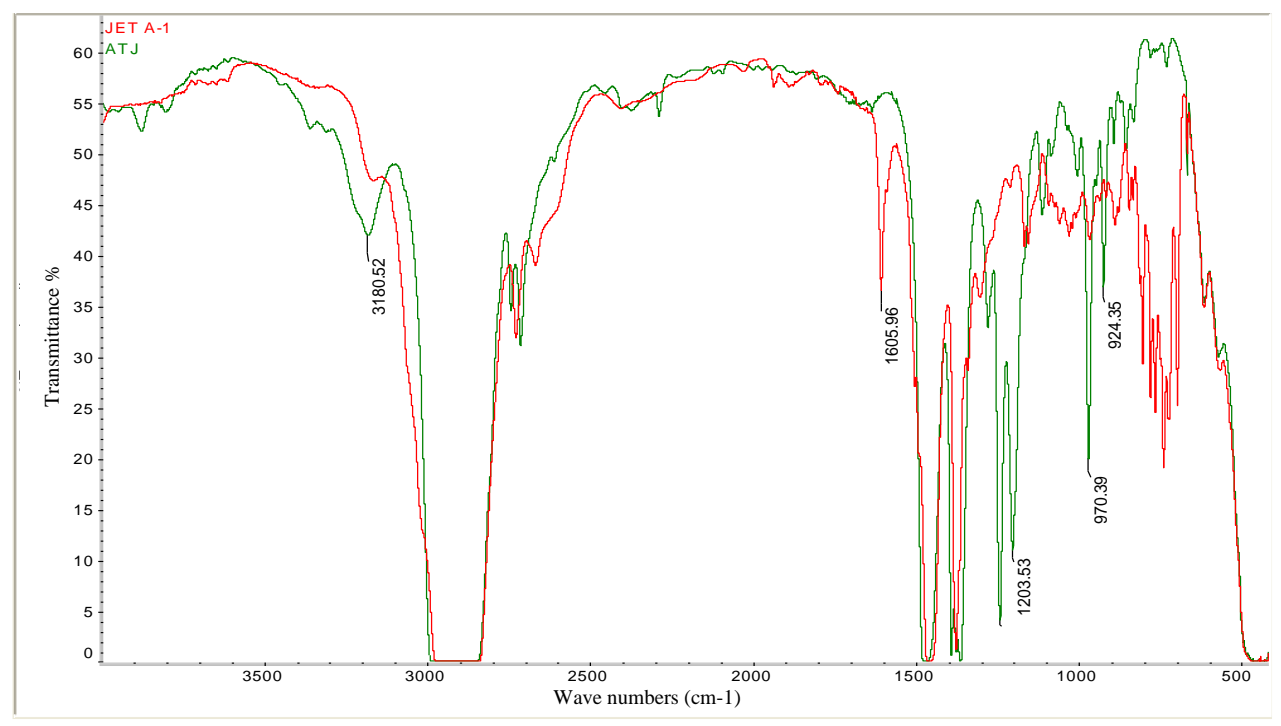

Fig. 3. Total infrared spectrum for the JET A-1 aviation fuel and the ATJ-SPK hydrocarbon biofuel 


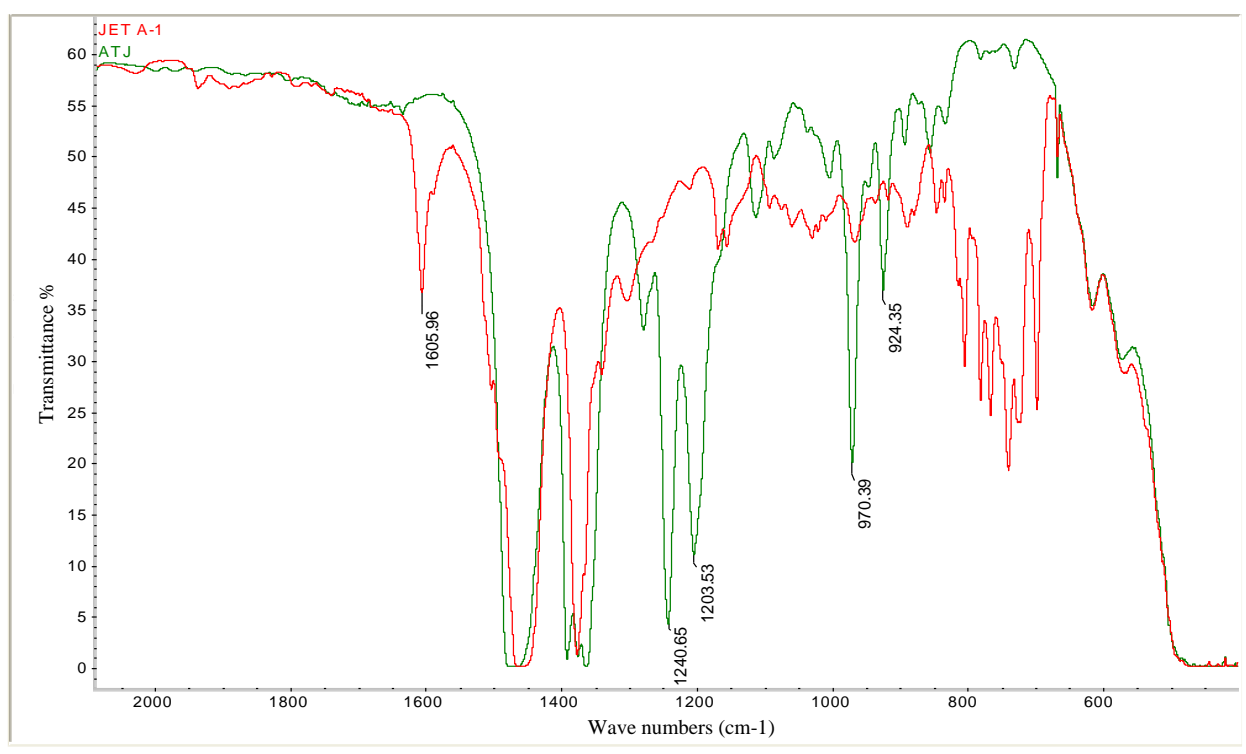

Fig. 4. Infrared spectrum for the JET A-1 aviation fuel and the ATJ-SPK hydrocarbon biofuel, for a wave number range of $2000-500 \mathrm{~cm}^{-1}$

The analysis of these spectra envisages a number of differences, both for the JET A-1 aviation fuel, as well as the hydrocarbon component. In the ATJ spectrum, within a wave number range of 4000-3000 $\mathrm{cm}^{-1}$ a characteristic peak for the O-H group bond appears; it is the residue after a substrate used to make the product. The peaks visible for a wave number range of 1260-900 $\mathrm{cm}^{-1}$ provide C-O tensioning bonds in secondary and tertiary alcohols. When analysing the JET A-1 aviation fuel infrared spectrum relative to the ATJ spectrum, significant difference for the 2000- $1500 \mathrm{~cm}^{-1}$ and $720-690 \mathrm{~cm}^{-1}$ ranges can be observed, with these peaks characteristic for aromatic compounds referred to when discussing the differences in the aviation and HEFA fuel.

Figures 5 and 6 show infrared spectra for a hydrocarbon biofuel in the HEFA technology and the ATJ hydrocarbon biofuel. Figures 5 and 6 show infrared spectra for a hydrocarbon biofuel in the HEFA technology and the ATJ hydrocarbon biofuel. 


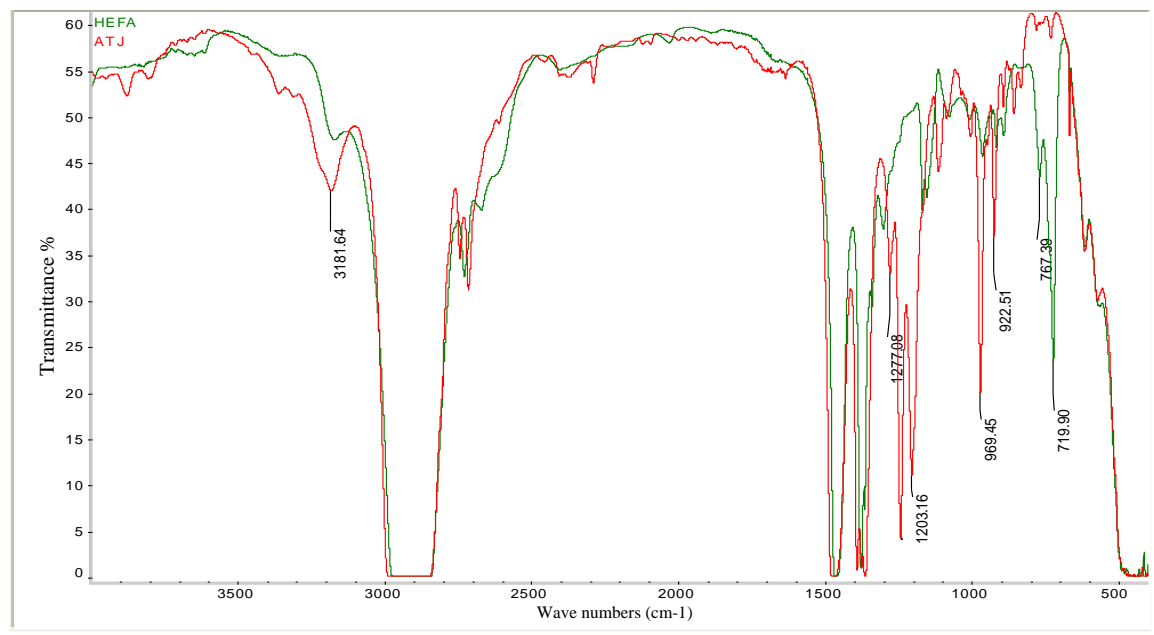

Fig. 5. Total infrared spectrum for the ATJ-SPK and HEFA hydrocarbon biofuel

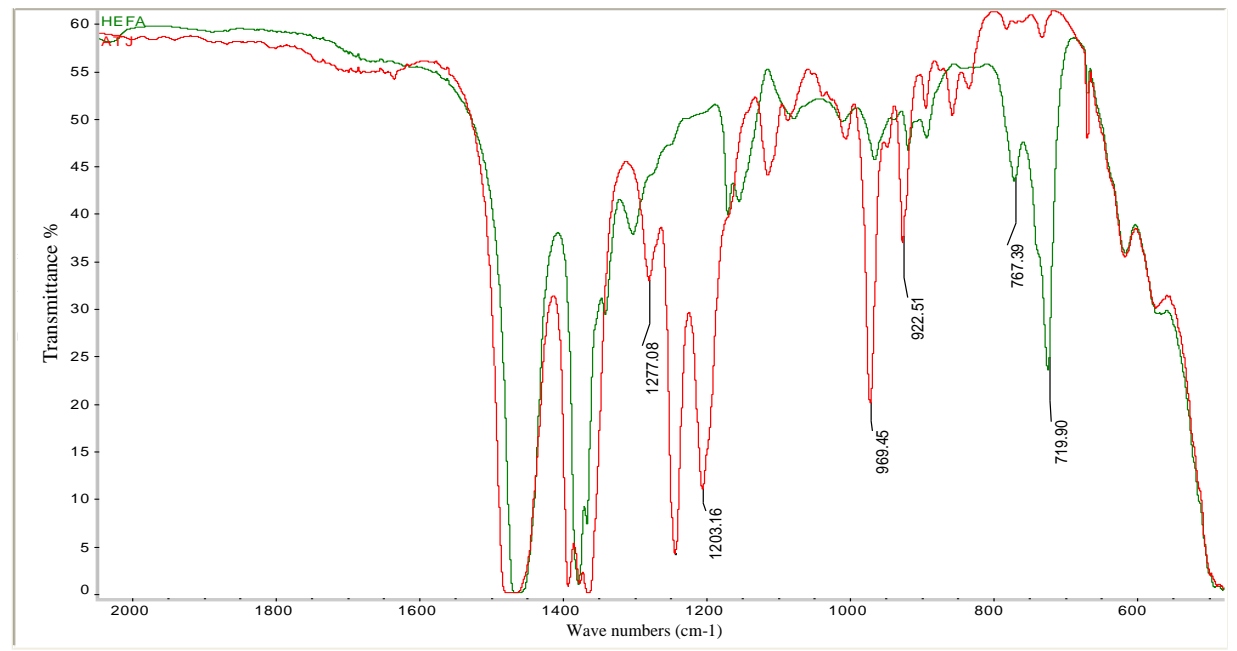

Fig. 6. Infrared spectrum for the ATJ-SPK and HEFA hydrocarbon biofuel, in the wave number range of 2000-500 $\mathrm{cm}^{-1}$

A number of differences can be seen when analysing the spectra of these two hydrocarbon biofuels. In the ATJ spectrum, within a wave number range of $4000-3000 \mathrm{~cm}^{-1} \mathrm{a}$ characteristic peak appears for the O-H group tensioning bond, which is the residue after a substrate used to make the product. The peaks visible for a wave number range of $1260-900 \mathrm{~cm}^{-1}$ provide C-O tensioning bonds in secondary and tertiary alcohols. When 
analysing the HEFA infrared spectrum, we can see significant differences in the $800-690 \mathrm{~cm}^{-1}$ range, with peaks characteristic for the $\mathrm{C}-\mathrm{H}$ bond in paraffins.

\section{Conclusions}

1. The infrared spectroscopy method enables quick, qualitative identification through indicating differences between the analysed aviation fuel and hydrocarbon biofuel, and between HEFA-SKP and ATJ-SPK hydrocarbon biofuels.

2. The spectrum of a mineral aviation fuels differs from the hydrocarbon biofuel spectrum in terms of the presence of aromatic compounds in the sample, which provide characteristic peaks within the $2000-1500 \mathrm{~cm}^{-1}$ and $720-690 \mathrm{~cm}^{-1}$ wave number ranges.

3. The ATJ-SPK hydrocarbon biofuel spectrum differs significantly from the mineral aviation fuel spectrum, and peaks characteristic for alcohol used to produce the component appear in the $4000-3000 \mathrm{~cm}^{-1}$ and $1260-900 \mathrm{~cm}^{-1}$ wave number ranges.

4. The spectra for ATJ-SPK and HEFA-SPK hydrocarbon biofuels differs in terms of the $4000-3000 \mathrm{~cm}^{-1}, 1260-900 \mathrm{~cm}^{-1}$ and $800-690 \mathrm{~cm}^{-1}$ wave numbers, and the analysis of these spectra enables a qualitative analysis of the used hydrocarbon biofuel.

As a result of the conducted tests it was concluded that infrared spectrometry allowed the identification of the hydrocarbon fuel type - distinguishing between mineral fuel, HEFA synthetic biofuel and ATJ synthetic biofuel.

The next research stage will involve attempts aimed at indicating, whether the infrared spectrometry method is suitable for the identification of mineral aviation fuel with hydrocarbon biocomponents, and determining which biocomponent was added to the fuel.

\section{References}

1. ASTM D 7566-2019: Standard Specification for Aviation Turbine Fuel Containing Synthesized Hydrocarbons.

2. Coates J.: Interpretation of Infrared Spectra, A Practical Approach. John Cotaes, Newtown 2006.

3. docplayer.pl/40732778-Cw-10-techniki-spektroskopii-w-podczerwieni-w-analiziecial-stalych.html

4. farmacja.cm.uj.edu.pl/uploads/2019/02/Spektroskopia-w-podczerwieni-IR.pdf

5. Kulczycki A.: Wstępne badania wpływu biokomponentów na przebieg procesu termicznej degradacji paliw do turbinowych silników lotniczych [Preliminary study of the impact of biocomponents on the course of the aircraft turbine engine fuel thermal degradation process]. Opracowanie wewnętrzne ITWL, Warszawa 2019. 
6. Jankowski S., Potrzebowski M., Sochacki M.: Spektroskopowe metody identyfikacji związków organicznych [Spectroscopic methods for the identification of organic compounds]. Wydawnictwo Naukowe PWN, Warszawa 2012. 


\section{ZASTOSOWANIE SPEKTROMETRII W PODCZERWIENI W BADANIACH PALIW I BIOPALIW DO TURBINOWYCH SILNIKÓW LOTNICZYCH}

\section{Wprowadzenie}

Dynamiczny rozwój transportu samochodowego i lotniczego, który miał miejsce na przełomie XX i XXI wieku, doprowadził do tego, że niespodziewanie szybko wzrósł popyt na paliwa mineralne, otrzymywane z przeróbki ropy naftowej. Zauważono, że zasoby tego naturalnego źródła bardzo szybko się kurczą i przy tak ogromnym zużyciu, mogą zabezpieczyć potrzeby w skali globalnej na około 40 lat. Powstała potrzeba zastępowania tradycyjnych paliw zamiennikami, które można otrzymywać ze źródeł odnawialnych.

Drugim ważnym powodem zastępowania paliw mineralnych zamiennikami, jest efekt cieplarniany. W wyniku intensywnego rozwoju transportu samochodowego i lotniczego, wzrosła emisja $\mathrm{CO}_{2}$. Wiele krajów postanowiło wdrożyć program, mający na celu zahamowanie wzrostu emisji $\mathrm{CO}_{2}$, poprzez zastosowanie biopaliw [5].

W transporcie samochodowym od około 20 lat wdrożone zostały biokomponenty i biopaliwa. Powszechnie stosowanymi biokomponentami do komponowania paliw są: FAME jako biokomponent oleju napędowego i bioetanol jako biokomponent benzyn samochodowych. W odniesieniu do paliw lotniczych, w ostatnim dziesięcioleciu rozwijane są technologie wytwarzania biopaliw węglowodorowych, które przeznaczone będą do zasilania silników o zapłonie samoczynnym i turbinowych silników lotniczych [5]. Analizując najnowszą literaturę techniczną, można zauważyć, że badania prowadzone na świecie wskazują, że biokomponentami stosowanymi w lotnictwie będą biowęglowodory komponenty węglowodorowe otrzymywane z biomasy. Posiadają one budowę chemiczną zbliżoną do paliw otrzymywanych z ropy naftowej, niestety jednak ich właściwości różnią się od własności stosowanych dotychczas paliw mineralnych.

Podstawowym dokumentem, który reguluje międzynarodowe przepisy dotyczące lotnictwa, jest Konwencja podpisana 7 grudnia 1944 r. w Chicago. Przedstawia ona ogólny podział lotnictwa na cywilne i państwowe. W skali europejskiej, wiodącym dokumentem dla lotnictwa cywilnego jest: Rozporządzenie Komisji (WE) Nr 859/2008 z dnia 20 sierpnia 2008 r. zmieniające Rozporządzenia Rady (EWG) Nr 3922/91 z dnia 16 grudnia 1991 r. w sprawie harmonizacji wymagań technicznych i procedur administracyjnych w dziedzinie lotnictwa cywilnego, w odniesieniu do wspólnych wymagań technicznych i procedur administracyjnych, mających zastosowania do komercyjnego transportu lotniczego. 
W Polsce podstawowym aktem prawnym, którego przepisy w całości dotyczą lotnictwa cywilnego, jest Ustawa z dnia 3 lipca 2002 r. Prawo Lotnicze. W przypadku Polskich Sił Powietrznych, na poziomie organu naczelnego, jest ono regulowane Decyzjami Ministra Obrony Narodowej, natomiast na poziomie organu centralnego przez wiele niezależnych od siebie instytucji wojskowych, takich jak: Dowództwo Generalne RSZ, Sztab Generalny WP, Inspektorat Sił Powietrznych, Inspektorat Sił Wsparcia SZ, Dowództwo Operacyjne RSZ, Komisję Badań Wypadków Lotniczych (KBWL LP). Standaryzacja systemu bezpieczeństwa jest utrudniona ze względu na taki stan organizacyjny, który powoduje rozpraszanie kompetencji i uprawnień decyzyjnych dotyczących lotnictwa wojskowego na wiele instytucji wojskowych. Wymogi techniczne oraz sposób postępowania z paliwem lotniczym regulują międzynarodowe standardy JIG, które powołują dwa standardy ASTM regulujące proces certyfikacji dla nowego produktu:

- ASTM D 4054 - Standard Practice for Qualification and Approval of New Aviation Turbine Fuels and Fuel Additives,

- ASTM D 7566 - Standard Specification for Aviation Turbine Fuel Containing Syntesized Hydrocabons.

\section{Rodzaje paliw syntetycznych dopuszczonych do stosowania}

W normie ASTM D 7566 „Standard Specification for Aviation Turbine Fuel Containing Syntesized Hydrocabons" [1] wymieniono rodzaje paliw syntetycznych, które można dodawać do paliwa lotniczego mineralnego oraz określono minimalne wymagania jakościowe dla poszczególnych biokomponentów. Norma opisuje pięć typów biokomponentów węglowodorowych, które różnią się właściwościami fizykochemicznym, a różnice wynikają z zastosowanej technologii wytwarzania.

1. Załącznik A.1 - określa wymagania dla syntetycznej nafty parafinowej (FT-SPK), otrzymywanej w procesie syntezy Fischer-Tropscha. W procesie tym wykorzystuje się frakcje biodegradowalnych, stałych odpadów komunalnych, rolniczych, leśnych oraz biomasę pozyskiwaną z celowych upraw drzewnych i energetycznych.

2. Załącznik A.2 - określa wymagania dla syntetycznej nafty parafinowej (HEFASPK), otrzymywanej w procesie hydrorafinowania estrów i kwasów tłuszczowych. W procesie tym wykorzystuje się głównie tłuszcze.

3. Załącznik A.3 - określa wymagania dla syntetycznej izoparafiny (SIP) otrzymywanej w procesie fermentacji cukrów. W procesie tym wykorzystuje się głównie produkty piekarnicze i cukiernicze.

4. Załącznik A.4 - określa wymagania dla syntetycznej nafty parafinowej wzbogaconej aromatami (FT-SPK/A), otrzymywanej w procesie syntezy Fischer-Tropscha, w której zawartość związków aromatycznych celowo zwiększa się, przez 
alkilowanie lekkich aromatów niepochodzących z ropy naftowej (głównie benzenu). W procesie tym wykorzystuje się głównie biomasę pochodzącą ze stałych odpadów komunalnych, odpadów rolniczych i leśnych.

5. Załącznik A.5 - określa wymagania dla syntetycznej nafty otrzymywanej z alkoholi (ATJ-SPK), w której izobutanol lub etanol poddawany jest szeregowi procesów dehydratacji, oligomeryzacji i uwodornienia. W procesie tym wykorzystuje się głównie izobutanol pochodzący z surowców odnawialnych, takich jak: odpady cukrowe, kukurydziane lub leśne.

Zastosowanie różnych technologii wytwarzania, poszczególnych biokomponentów węglowodorowych, powoduje, że wymienione biopaliwa węglowodorowe mają różny skład jakościowy. Jednym z nowych problemów w eksploatacji paliw do turbinowych silników lotniczych jest identyfikacja nie-naftowych komponentów, w tym węglowodorowych biokomponentów. W niniejszym artykule przedstawiono wyniki wstępnych badań nad wykorzystaniem spektrometrii w podczerwieni, jako techniki analizy instrumentalnej umożliwiającej szybką, jakościową identyfikację zastosowanego biokomponentu węglowodorowego.

\section{Spektrometria w podczerwieni - wprowadzenie}

Zakres podczerwieni obejmuje widmo promieniowania elektromagnetycznego między obszarem widzialnym a mikrofalowym, tzn. między 14300 a $200 \mathrm{~cm}^{-1}$. W badaniach struktury związków organicznych największe znaczenie ma obszar podczerwieni właściwej (4000-700 $\left.\mathrm{cm}^{-1}\right)$, z którym sąsiaduje podczerwień daleka $\left(700-200 \mathrm{~cm}^{-1}\right)$ oraz podczerwień bliska (14300-4000 $\mathrm{cm}^{-1}$ ). Absorpcji promieniowania w zakresie $4000-700 \mathrm{~cm}^{-1}$ odpowiadają przejścia oscylacyjno-rotacyjne [4].

Grupy funkcyjne, a także inne charakterystyczne ugrupowania atomów, zwykle absorbują promieniowanie podczerwone w stosunkowo wąskim obszarze częstości, niezależnie od budowy reszty cząsteczki. Dzięki temu spektroskopia w podczerwieni jest niezastąpioną metodą identyfikacji grup funkcyjnych i innych elementów struktury związku [4].

Nawet proste związki chemiczne mają na tyle skomplikowane widmo w podczerwieni, że porównanie widm dwóch substancji jest znakomitym testem ich identyczności. Nie zdarza się bowiem, by dwa różne związki, nie będące enancjomerami, miały identyczne widma w podczerwieni [4].

Absorpcja promieniowania podczerwonego powoduje zmiany energii wzbudzeń oscylacyjnej i rotacyjnej, przy czym ważniejszą rolę odgrywają wzbudzenia oscylacyjne, ponieważ posiadają większą energię niż wzbudzenia rotacyjne. W cząsteczce rozróżnia się dwa rodzaje drgań oscylacyjnych:

- drgania deformacyjne, np.: skręcające, nożycowe, kołyszące, które powodują zmianę kąta między wiązaniami atomów, 
- drgania rozciągające symetryczne lub asymetryczne, które charakteryzują się rytmicznym ruchem wzdłuż osi wiązania, powoduję one, że odległość pomiędzy atomami zmniejsza się lub zwiększa.

Techniki pomiarowe można podzielić na dwie grupy: transmisyjną i refleksyjną. Techniką transmisyjną, poprzez pomiar intensywności promieniowania po przejściu przez próbkę, uzyskuje się widmo oscylacyjne. Próbki ciekłe i gazowe oznacza się w naczyniach pomiarowych zwanych kuwetami, które posiadają okienka wykonane z materiałów przezroczystych dla podczerwieni tj.: $\mathrm{KBr}, \mathrm{NaCl}, \mathrm{ZnSe}$, zaś widma próbek stałych można mierzyć w pastylkach wykonanych np.: z halogenków litowców w zawiesinie w Nujolu (ciekłej parafinie), na płytkach krzemowych. Technika refleksyjna pozwala otrzymać widmo w podczerwieni poprzez pomiar promieniowania odbitego od próbki. Do pomiaru promieniowania odbitego służą rozmaite układy optyczne stosowane w przystawkach do spektrometrów. Metoda osłabionego całkowitego wewnętrznego odbicia (ATR) wykorzystuje zjawisko całkowitego wewnętrznego odbicia światła [3], dedykowana jest dla próbek stałych i bez względu na ich grubość uzyskujemy widmo jakościowe.

\section{Interpretacja widm w podczerwieni}

Widmo w podczerwieni jest wykresem zależności absorpcji od energii promieniowania. Miarą absorpcji promieniowania jest intensywność wiązki - transmitancja lub jej odwrotność absorbancja. Pełna interpretacja widma jest trudna, ponieważ w obrębie jednej cząsteczki występuje wiele drgań deformacyjnych i rozciągających. Widmo zawiera wiele różnych pasm odpowiadających tym drganiom. Poszczególne rodzaje wiązań mając podobną różnicę energii pomiędzy poziomami oscylacyjnymi, absorbują promieniowanie o charakterystycznej częstotliwości dając pasmo w tym samym zakresie, niezależnie od innych szczegółów struktury cząsteczki. Oznacza to, że te same grupy funkcyjne (np. $\mathrm{C}=\mathrm{O}$, $\mathrm{N}-\mathrm{H}, \mathrm{O}-\mathrm{H})$ w różnych związkach dają charakterystyczne pasma absorpcyjne, które znajdują się w porównywalnym zakresie liczb falowych. W celach identyfikacji obszar zakresu liczb falowych 4000-400 $\mathrm{cm}^{-1}$ można podzielić na cztery części:

1. Obszar 4000-2500 cm-1 odpowiada absorpcji wynikającej najczęściej z obecności w cząsteczce grup N-H, C-H-, O-H. Pasma w tym zakresie odpowiadają drganiom rozciągającym.

2. Obszar 2500-2000 $\mathrm{cm}^{-1}$, pasma absorpcji w tym zakresie wskazują na obecność w związku grup zawierających wiązania potrójne np. alkiny $\mathrm{C} \equiv \mathrm{C}$, nitryle $\mathrm{C} \equiv \mathrm{N}$.

3. Obszar 2000-1500 $\mathrm{cm}^{-1}$, pasma $\mathrm{w}$ tym zakresie pochodzą głównie od różnego rodzaju drgań rozciągających wiązań podwójnych $(\mathrm{C}=\mathrm{O}, \mathrm{C}=\mathrm{C}, \mathrm{C}=\mathrm{N})$.

4. Zakres poniżej $1500 \mathrm{~cm}^{-1}$ nazywany ,zakresem daktyloskopowym” posiada układ pasm charakterystyczny dla danej cząsteczki. Są tutaj pasma drgań rozciągających wiązań pojedynczych np. C-C, C-O, C-N oraz wiele pasm odpowiadających drganiom deformacyjnym. Zakres ten wykorzystywany jest do identyfikacji badanej substancji na podstawie porównania widma $\mathrm{w}$ podczerwieni $\mathrm{z}$ widmem 
związku wzorcowego i, tak jak w daktyloskopii identyczność zakresu „odcisku palca”, stanowi potwierdzenie identyczności badanego związku z wzorcem [4].

\section{Analiza wyników}

W celu określenia możliwości wykorzystania techniki spektroskopii w podczerwieni wykonano widma $\mathrm{w}$ podczerwieni dla próbki paliwa lotniczego JET A-1 oraz dwóch komponentów węglowodorowych HEFA-SPK i ATJ-SPK. Pomiar wykonano w kuwecie ze zmienną drogą optyczną, ze szkiełkami ZnSe.

Na rys. 1 i 2 zestawiono widma w podczerwieni dla paliwa lotniczego JET A-1 i biopaliwa węglowodorowego $\mathrm{z}$ technologii HEFA, czyli otrzymanego w procesie hydrorafinowania estrów i kwasów tłuszczowych.

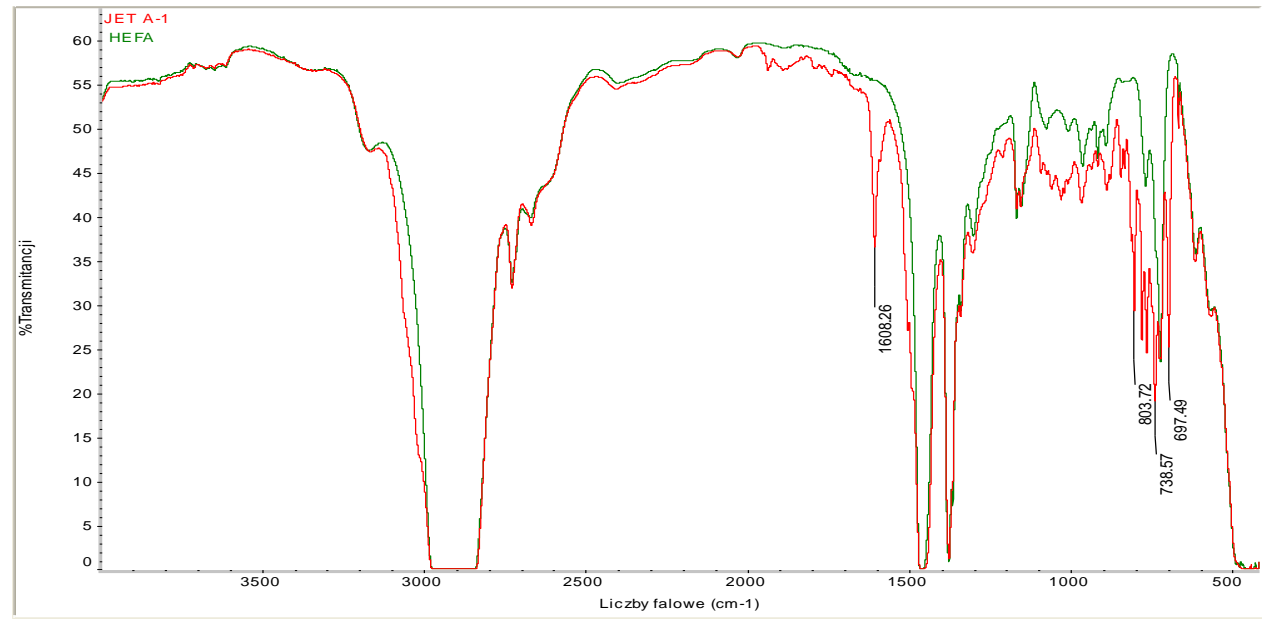

Rys. 1. Całościowe widmo w podczerwieni dla paliwa lotniczego JET A-1 i biopaliwa węglowodorowego z technologii HEFA 


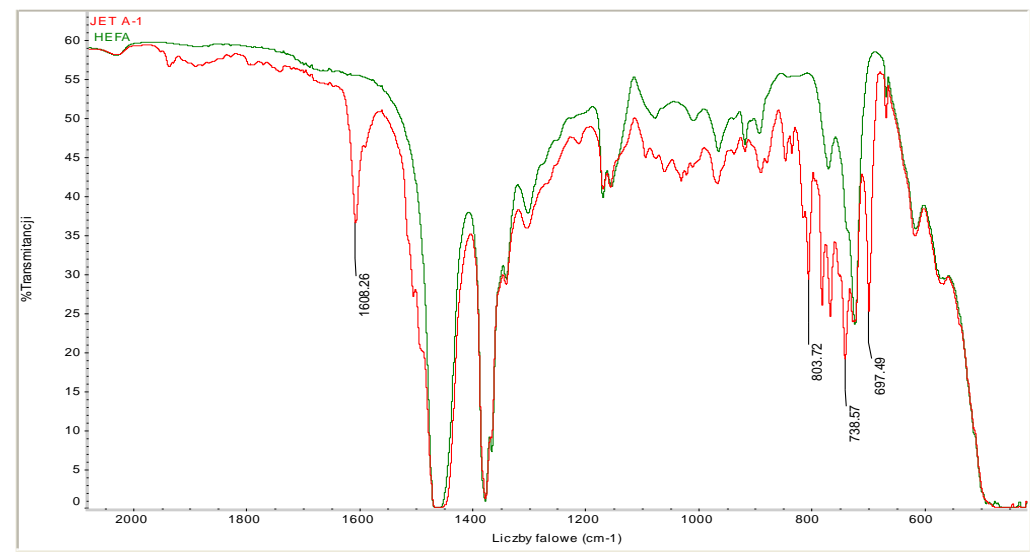

Rys. 2. Widmo w podczerwieni dla paliwa lotniczego JET A-1 i biopaliwa węglowodorowego z technologii HEFA w zakresie liczby falowej $2000-500 \mathrm{~cm}^{-1}$

Analizując te widma w podczerwieni, zauważa się znaczne różnice w obszarze liczby falowej 2000-1500 $\mathrm{cm}^{-1}$, komponent węglowodorowy w tym obszarze nie posiada pików chrakterystycznych, które ma paliwo lotnicze JET A-1. Długi, ostry piki o liczbie falowej około $1600 \mathrm{~cm}^{-1}$, pojawia się, gdy obecne są związki aromatyczne, daje go wiązanie $\mathrm{C}=\mathrm{C}$, które wystepuje w pierścieniu aromatycznym. W zakresie liczby falowej $1500-700 \mathrm{~cm}^{-1}$, również zauważalne są różnice, $\mathrm{w}$ zarejestrowanych widmach $\mathrm{w}$ podczerwieni. $\mathrm{W}$ paliwie lotniczym JET A-1, w obszarze liczby falowej 900-600 $\mathrm{cm}^{-1}$, widoczne są piki, które są charakterystyczne dla wiązania $\mathrm{C}-\mathrm{H} \mathrm{w}$ konfuguracji $\mathrm{sp}^{2}$, w pierścieniu aromatycznym, odpowiedzialne za to są mono- i parapodstawniki przy pierścieniu aromatycznym.

$\mathrm{Na}$ rys. 3 i 4 zestawiono widma w podczerwieni dla paliwa lotniczego JET A-1 i biopaliwa węglowodorowego ATJ, który otrzymano z technologii, w której izobutanom lub etanol poddawany jest szeregowi procesów dehydratacji i uwodornienia.

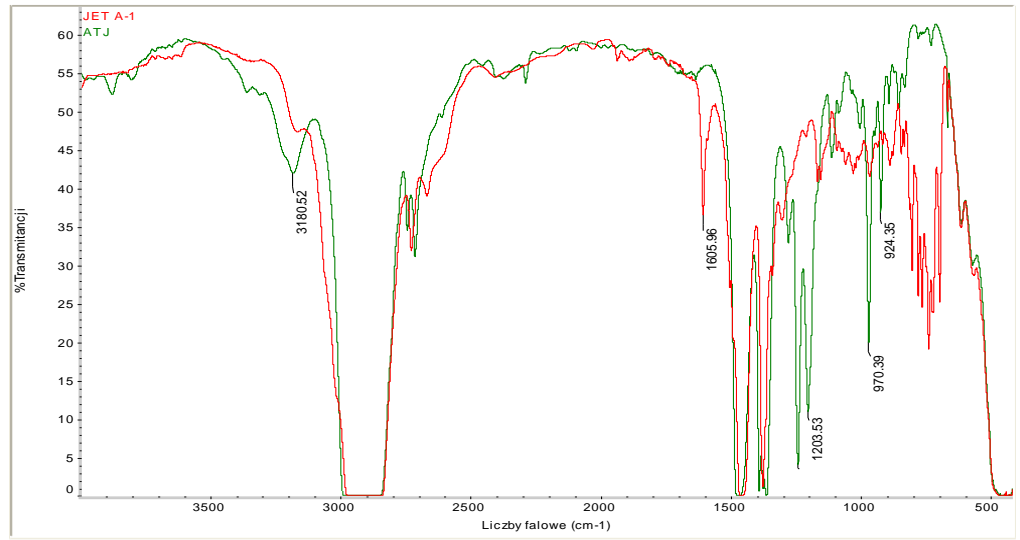

Rys. 3. Całościowe widmo w podczerwieni dla paliwa lotniczego JET A-1 i biopaliwa węglowodorowego ATJ-SPK 


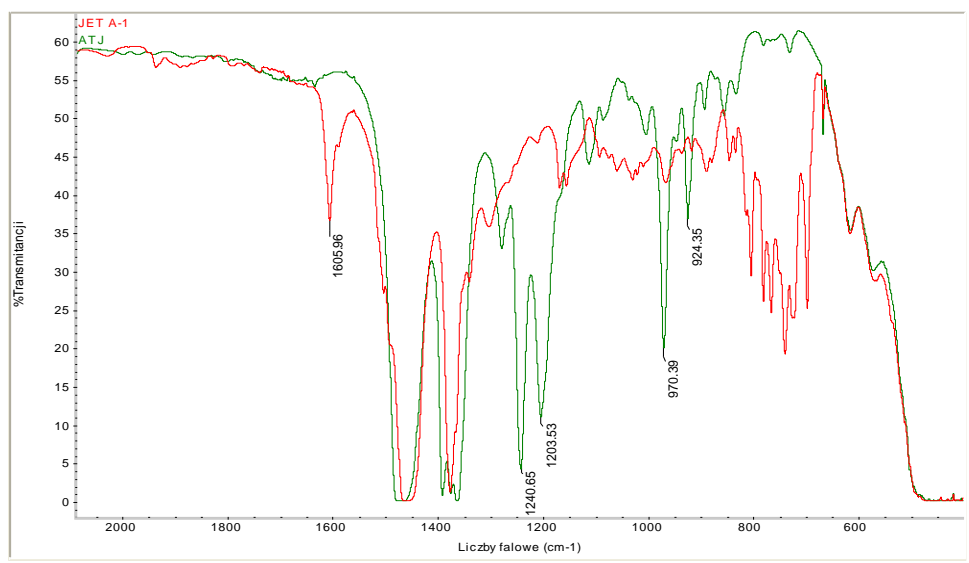

Rys. 4. Widmo w podczerwieni dla paliwa lotniczego JET A-1 i biopaliwa węglowodorowego ATJSPK w zakresie liczby falowej $2000-500 \mathrm{~cm}^{-1}$

Analizując te widma, widać szereg różnic, zarówno dla widma paliwa lotniczego JET A-1, jak i dla biokomponentu węglowodorowego. W widmie ATJ, w zakresie liczby falowej 4000-3000 $\mathrm{cm}^{-1}$ pojawia się charakterystyczny pik, dla wiązania rozciągającego grupy $\mathrm{O}-\mathrm{H}$, jest to pozostałość po substracie, który został użyty do wytworzenia produktu. Widoczne piki przy zakresie liczby falowej $1260-900 \mathrm{~cm}^{-1}$, dają wiązania rozciągające C-O w alkoholach dwu- i trzeciorzędowych. Analizując widmo w podczerwieni paliwa lotniczego JET A-1 względem widma ATJ, zauważa się znaczne różnice $\mathrm{w}$ obszarach 2000- $1500 \mathrm{~cm}^{-1}$ oraz 720-690 $\mathrm{cm}^{-1}$, piki te są charakterystyczne, dla związków aromatycznych, o których wspomniano omawiając różnice w widmie paliwa lotniczego i HEFA.

Na rys. 5 i 6 zestawiono widma w podczerwieni biopaliwa węglowodorowego $\mathrm{z}$ technologii HEFA oraz biopaliwa węglowodorowego ATJ.

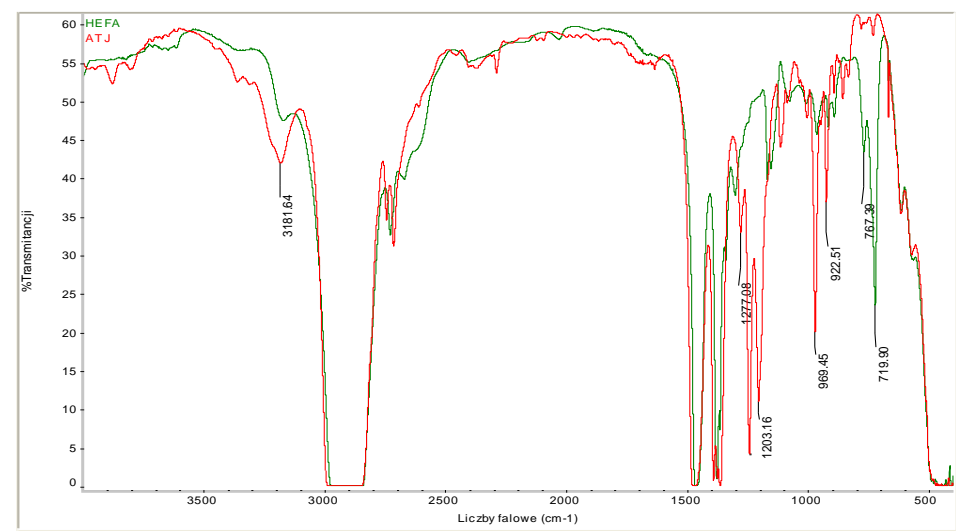

Rys. 5. Całościowe widmo w podczerwieni dla biopaliwa węglowodorowego ATJ-SPK i HEFA 


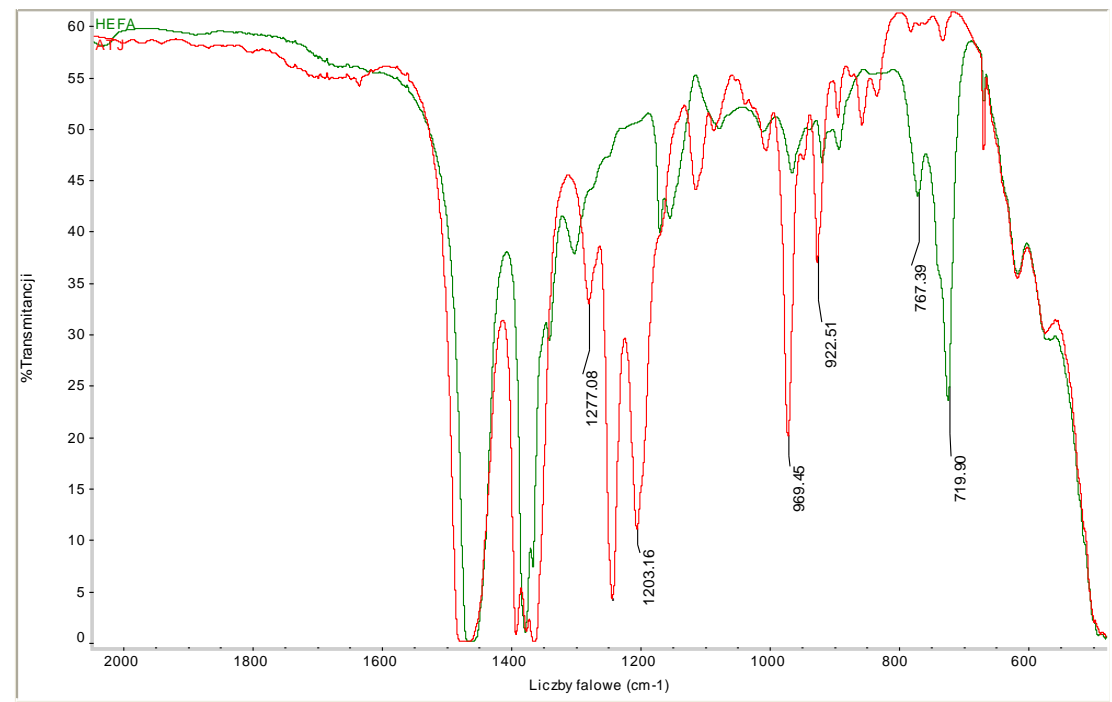

Rys. 6. Widmo w podczerwieni dla biopaliwa węglowodorowego ATJ-SPK i HEFA w zakresie liczby falowej $2000-500 \mathrm{~cm}^{-1}$

Analizują widma dwóch biopaliw węglowodorowych, widać wiele różnic. W widmie ATJ, w zakresie liczby falowej $4000-3000 \mathrm{~cm}^{-1}$ pojawia się charakterystyczny pik, dla wiązania rozciągającego grupy $\mathrm{O}-\mathrm{H}$, jest to pozostałość po substracie, który został użyty do wytworzenia produktu. Widoczne piki przy zakresie liczby falowej $1260-900 \mathrm{~cm}^{-1}$, dają wiązania rozciągające $\mathrm{C}-\mathrm{O} \mathrm{w}$ alkoholach dwu- i trzeciorzędowych. Analizując widmo w podczerwieni HEFA, zauważa się znaczne różnice w obszarze $800-690 \mathrm{~cm}^{-1}$ widoczne są piki, które są charakterystyczne dla wiązania C-H w parafinach.

\section{Wnioski}

1. Metoda spektroskopii w podczerwieni umożliwia szybką, jakościową identyfikację, poprzez wskazanie różnic, pomiędzy analizowanym paliwem lotniczym i biopaliwem węglowodorowym, oraz pomiędzy biopaliwami węglowodorowymi HEFA-SKP i ATJ-SPK.

2. Widmo mineralnego paliwa lotniczego różni się od widma biopaliwem węglowodorowego, ze względu na obecność w próbce związków aromatycznych, które dają charakterystyczne piki w obszarze liczby falowej $2000-1500 \mathrm{~cm}^{-1}$ oraz $720-690 \mathrm{~cm}^{-1}$.

3. Widmo biopaliwa węglowodorowego ATJ-SPK różni się znacznie od widma mineralnego paliwa lotniczego, w zakresie liczby falowej $4000-3000 \mathrm{~cm}^{-1}$ oraz $1260-900 \mathrm{~cm}^{-1}$, pojawiają się charakterystyczne piki dla alkoholu, który został użyty do produkcji komponentu. 
4. Widma biopaliw węglowodorowych ATJ-SPK i HEFA-SPK różnią w zakresie liczby falowej 4000-3000 $\mathrm{cm}^{-1}, 1260-900 \mathrm{~cm}^{-1}$ oraz 800-690 $\mathrm{cm}^{-1}$, analiza tych widm, umożliwia jakościową identyfikację zastosowanego biopaliwa węglowodorowego.

W rezultacie przeprowadzonych badań stwierdzono, że spektrometria w podczerwieni pozwala na identyfikację rodzaju węglowodorowego paliwa - odróżnienie paliwa mineralnego, syntetycznego biopaliwa HEFA i syntetycznego biopaliwa ATJ.

W kolejnym etapie prac badawczych, zostaną podjęte próby, mające na celu wskazanie, czy metoda spektrometrii w podczerwieni będzie odpowiednia do identyfikacji mieszanek mineralnego paliwa lotniczego z biokomponentami węglowodorowymi oraz określenia, jaki biokomponent został do paliwa dodany.

\section{Literatura}

1. ASTM D 7566-2019: Standard Specification for Aviation Turbine Fuel Containing Synthesized Hydrocarbons.

2. Coates J.: Interpretation of Infrared Spectra, A Practical Approach. John Cotaes, Newtown 2006.

3. docplayer.pl/40732778-Cw-10-techniki-spektroskopii-w-podczerwieni-w-analiziecial-stalych.html

4. farmacja.cm.uj.edu.pl/uploads/2019/02/Spektroskopia-w-podczerwieni-IR.pdf

5. Kulczycki A.: Wstępne badania wpływu biokomponentów na przebieg procesu termicznej degradacji paliw do turbinowych silników lotniczych. Opracowanie wewnętrzne ITWL, Warszawa 2019.

6. Jankowski S., Potrzebowski M., Sochacki M.: Spektroskopowe metody identyfikacji związków organicznych. Wydawnictwo Naukowe PWN, Warszawa 2012. 